\section{СТАТИСТИКА, ЕСЕП ЖӘНЕ АУДИТ}

\section{СТАТИСТИКА, УЧЕТ И АУДИТ}

\section{STATISTICS, ACCOUNT AND AUDIT}

ISSN 1563-2415

Ежеквартальный научнопрактический журнал издается с 1999 года.

№ 1(84) 2022

Учредитель «Алматинский гуманитарно-экономический университет»

Алматинский гуманитарно-экономический университет

Главный редактор

Досаева С.К.

Заместители гл. редактора:

Корвяков В.А. - д.п.н., проф., ректор АГЭУ

Сейтхамзина Г.Ж. - к.э.н., проф., проректор по науке и инновациям АГЭУ

\section{Члены редколлегии:}

Амирханова Г.А. - доктор $\mathrm{PhD}$, снс ИИВТ КН МОН РК, г.Нур-Султан, Казахстан

Бекенова Л.М. - к.э.Н., профессор, проректор по академической работе АГЭУ

Дауренбеков А.К. - к.э.н., проф. АГЭУ, г. Алматы, Казахстан

Дырка Стефан - д.э.н., проф., Верхнесилезский экономический Университет имени Вой- цеха Корфанти в Катовицах, Польша

Ерж⿻анов М.С. - д.э.н., проф., партнер «Grant Thornton», г.Алматы, Казахстан

Ешпанова Д.Д. - к.э.н., доцент кафедры "Учет, аудит и статистика" АГЭУ, г.Алматы, Казахстан

Макыш С.Б. - д.э.н., проф., декан экономического факультета, ЕНУ им.Л.Н.Гумилева, г.Нур-Султан, Казахстан

Мезенцева T.M. - д.э.н., профессор департамента учета, анализа и аудита Финансового Университета при правительстве РФ, г.Москва, Россия

Назарова В.Л. - Д.э.н., проф., зав. кафедрой "Учет, аудит и статистика" АГЭУ, г.Алматы, Казахстан

Рахметова P.У. - д.э.н, проф., Туран - Астана, Нурсултан, Казахстан

Сейдахметова Ф.С. - д.э.н., проф. кафедры "Учет, аудит и статистика" АГЭУ, г.Алматы, Казахстан

Taunoв T.A. - к.э.н., проф., АГЭУ, г.Алматы, Казахстан

Тайгашинова К.T. - д.э.Н., проф кафедры "Учет, аудит и статистика", АГЭУ, г.Алматы, Казахстан

Шокаманов Ю.К. - Д.э.н., проф., г.Нур-Султан, Казахстан

\section{Издательский центр}

Алматинского гуманитарно-

экономического университета

050035, г.Алматы,

ул.Жандосова, 59,

тел: +7 7273095820 ,

$+77273095815$

факс: + 77273093000

e-mail: zhurnal.aesa.99@mail.ru

www.journal.ageu.kz, www.ageu.kz

Ответственный за выпуск журнала Айтжанова Н.M.

Подписано в печать: 26.01.2022г.

Формат 70x108 1/16.

Бумага офсетная.

Тираж 300 экз.

\section{ИП «Аруна»}

г.Алматы, Алмалинский район, ул. Нурмакова, 26/195 кв. 49 e-mail: mail: iparuna@yandex.ru 
ISSN 1563-2415

Учреждение «Алматинский гуманитарно-экономический университет», 050035, г. Алматы, ул. Жандосова, 59, тел.(727) 309-58-20, 309-58-15, вн. 138 e-mail: zhurnal.aesa.99@mail.ru, aesa2005@mail.ru

Website: journal.ageu.kz, www.ageu.kz

Регистрационное свидетельство № 9099-Ж от 25.03.2008 г. выдано Министерством культуры и информации Республики Казахстан, Комитетом информации и архивов

Журнал включен в Российский индекс научного цитирования (РИНЦ) и размещается в научной электронной библиотеке (WWW.ELIBRARY.RU) (Лицензионный договор с ООО «НЭБ» № 133-03/2016 г.Москва 11 марта 2016 г.). 
Раман Ибрахим, Сюзана Бахарудин

МЕЛИМАУ ПОЛИТЕХНИКАЛЫҚ ИНСТИТУТЫНДА КОВИД-19

ПАНДЕМИЯСЫ КЕЗІНДЕ СИНХРОНДАЛҒАН ОНЛАЙН ОҚЫТУҒА

КЕНЕТ ӨТУ: ИНЖЕНЕРЛІК ФАКУЛЬТЕТІ СТУДЕНТТЕРІ

ПЕРСПЕКТИВАСЫН САНДЫК ЗЕРТТЕУ ...

Нориымах Осман

4IR ЭЛЕМЕНТТЕРІН ҚОЛДАНУ АРҚЫЛЫ ТЖКБ ЦИФРЛАНДЫРУ.

Тан Си Мин

ЦИФРЛІК МІНЕЗ-ҚҰЛЫҚТЫ ДАМЫТУ ЖӘНЕ МУЛЬТИФИКАЦИЯ МЕН ИННОВАЦИЯЛЫҚ ОҚЫТУ ҚҰРАЛЫ РЕТІНДЕ ИНТЕГРАЦИЯЛАУ:

ОҚУДАҒЫ СТУДЕНТТЕРДІН МІНЕЗ-ҚҰЛҚЫНА ӘСЕРІ.

\section{Тео Пей Киан}

ӨНДІРІСТІК СТУДЕНТТЕРДІ ОҚУ ТИІМДІЛІГІНЕ ОҚУ

ИННОВАЦИЯЛАРЫНЫҢ ӘСЕРІ ЖОҒАРЫ ОҚУ ОҚУЫНДАҒЫ

ДИЗАЙН.....

Дви Вахюнинсси, Сламет Утомо, Шри Сурачми, Сажида Досаева

КОВИД-19 ПАНДЕМИЯСЫ КЕЗІНДЕ ОНЛАЙН ОҚЫТУДЫН САПАСЫН

АРТТЫРУДАҒЫ КӨШБАСШЫНЫН РӨЛІ.

А.Адельбаева, А. Бекметова

АЗЫҚ-ТҮЛІКПЕН МОЛЫҚТЫРУДЫ ҚАМТАМАСЫЗ ЕТУ ҮШІН

АГРАРЛЫҚ НАРЫҚТЫ РЕТТЕУ.

А. Джумабаева, Д. Бабаш, А.Кенджасарова, Р.Арзикулова

ҚАЗАҚСТАННЫН АЗЫҚ-ТҮЛІК ҚАУІПСІЗДІГІН ҚАМТАМАСЫЗ ЕТУ:

ТЕОРИЯ, ӘДІСТЕМЕ ЖӘНЕ ПРАКТИКА

А. Нуртаева, С. Айткулова, А.Садвакасова, А.Кұрмантаева

КОММЕРЦИЯЛЫҚ БАНКТЕРДЕГІ ТӘУЕКЕЛДЕРДІ БАСҚАРУ ЖҮЙ-

ЕСІНІН ТИІМДІЛІГІН ТАЛДАУ.

\section{А.Рамазанов, С.Базылхан}

ҚОНАҚЖАЙЛЫЛЫҚТЫН КОНЦЕПТУАЛДЫҚ НЕГІЗДЕРІ.

А.Рамазанов, Ж.Куралов

ҚОНАҚ ҮЙ ІСІНІҢ ЭКОНОМИКАЛЫҚ СИПАТТАМАСЫ.

II.A. Topzaeвa

КОМПАНИЯ ҚЫЗМЕТІНДЕГІ ИНТЕРНЕТ МАРКЕТИНГ 


\section{СОДЕРЖАНИЕ}

Раман Ибрагим, Сюзана Бахарудин

ВНЕЗАПНЫЙ ПЕРЕХОД К СИНХРОНИЗИРОВАННОМУ ОНЛАЙНОБУЧЕНИЮ ВО ВРЕМЯ ПАНДЕМИИ COVID-19 В ПОЛИТЕХНИЧЕСКОМ ИНСТИТУТЕ МЕРЛИМАУ: КОЛИЧЕСТВЕННОЕ ИССЛЕДОВАНИЕ ПЕРСПЕКТИВ СТУДЕНТОВ ФАКУЛЬТЕТА МАШИНОСТРОЕНИЯ.............. 6

Норшыммах Осман

ОЦИФРОВКА ТVЕТ С ИСПОЛЬЗОВАНИЕМ ЭЛЕМЕНТОВ 4IR.

Тан Си Мин

РАЗРАБОТКА ЦИФРОВОГО ПОВЕДЕНИЯ И ИНТЕГРИРОВАНИЕ С МУЛЬТИФИКАЦИЕЙ В КАЧЕСТВЕ ИННОВАЦИОННОГО УЧЕБНОГО СРЕДСТВА: ВЛИЯНИЕ НА ПОВЕДЕНИЕ УЧАЩИХСЯ В ОБУЧЕНИИ.......

\section{Тео Пей Киан}

ВЛИЯНИЕ ОБУЧАЮЩИХ ИННОВАЦИЙ НА ЭФФЕКТИВНОСТЬ ОБУЧЕНИЯ СТУ ДЕНТОВ ПРОМЫШЛЕННЫХ ДИЗАЙН В ВЫСШЕМ ОБРАЗО-

ВАНИИ.

Dwi Wahyuningsih, Slamet Utomo, Sri Surachmi, Сажида Досаева

РОЛЬ РУКОВОДИТЕЛЯ В ПОВЫШЕНИИ КАЧЕСТВА ОНЛАЙН-

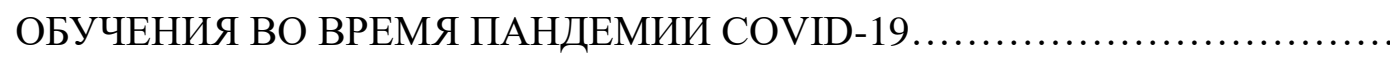

А.Адельбаева, А.Бекметова

РЕГУЛИРОВАНИЕ АГРАРНОГО РЫНКА ДЛЯ ОБЕСПЕЧЕНИЯ ПРОДО-

ВОЛЬСТВЕННОГО НАСЫЩЕНИЯ.

А. Джумабаева, Д. Бабаш, А.Кенджасарова, Р. Арзикулова ОБЕСПЕЧЕНИЕ ПРОДОВОЛЬСТВЕННОЙ БЕЗОПАСНОСТИ КАЗАХСТАНА: ТЕОРИЯ, МЕТОДОЛОГИЯ И ПРАКТИКА.

А. Нуртаева, С. Айткулова, А.Садвакасова А. Құрмантаева

АНАЛИЗ ЭФФЕКТИВНОСТИ СИСТЕМЫ УПРАВЛЕНИЯ РИСКАМИ В КОММЕРЧЕСКИХ БАНКАХ

\section{Рамазанов А., С.Базылхан}

КОНЦЕПТУАЛЬНЫЕ ОСНОВЫ ГОСТЕПРИИМСТВА.

Рамазанов А., Ж.Куралов

ЭКОНОМИЧЕСКИЕ ХАРАКТИРИСТИКИ ГОСТИНИЧНОГО ДЕЛА.

U.A Торгаева

ИНТЕРНЕТ - МАРКЕТИНГ В КОМПАНИЯХ 


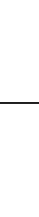

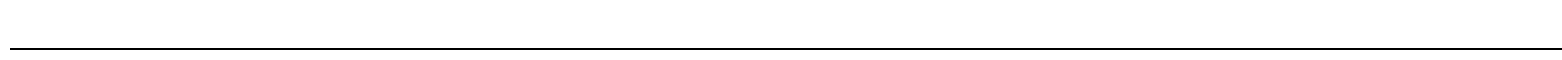

\section{Raman Ibrahim, Suzana Baharudin}

THE SUDDEN TRANSITION TO SYNCHRONIZED ONLINE LEARNING DURING THE COVID-19 PANDEMIC IN POLITEKNIK MERLIMAU: A QUANTITATIVE STUDY EXPLORING MECHANICAL ENGINEERING STUDENT'S PERSPECTIVES.

Norshymah Osman

DIGITALIZING TVET USING 4IR ELEMENTS.

Tan Si Min

DEVELOP DIGITAL STORYTELLING INTEGRATES WITH ANIMATION AS AN INNOVATIVE INSTRUCTIONAL TOOL: EFFECTS ON STUDENT'S BEHAVIOURAL ENGAGEMENT IN LEARNING.

Teo Pei Kian

THE EFFECT OF TEACHING INNOVATION ON LEARNING EFFECTIVENESS AMONG THE STUDENTS OF INDUSTRIAL

DESIGN IN HIGHER EDUCATION

Dwi Wahyuningsih, Slamet Utomo, Sri Surachmi, Sazhida Dossayeva

THE ROLE OF THE PRINCIPAL IN IMPROVING THE QUALITY OF ONLINE LEARNING DURING THE COVID-19 PANDEMIC

A. Adelbaeva Phd student, A. Bekmetova

REGULATION OF THE AGRICULTURAL MARKET TO ENSURE FOOD SATURATION

A. Dzhumabayeva, D. Babash, A. Kendzhasarova, R.Arzikulova

ENSURING FOOD SECURITY IN KAZAKHSTAN: THEORY, METHODOLOGY AND PRACTICE.

A. Nurtayeva, S. Aitkulova, A.Sadvakassova, A. Kurmantaeva

ANALYSIS OF THE EFFECTIVENESS OF THE RISK MANAGEMENT SYSTEM IN COMMERCIAL BANKS

Ramazanov A., C. Bazylhan

CONCEPTUAL BASIS OF HOSPITALITY.

Ramazanov A., Zh. Kuralov

ECONOMIC CHARACTERISTICS OF THE HOTEL BUSINESS

Torgaeva Sh.A

INTERNET MARKETING IN COMPANIES. 


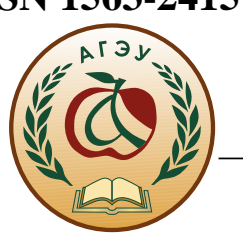

Статистика, учет и аудит, $\mathbf{4 ( 8 4 ) 2 0 2 2}$ стр. $68-75$

\author{
МРНТИ 06.71.07 \\ УДК 338.439 \\ https://doi.org/10.51579/1563-2415.2022-1.07
}

\title{
ENSURING FOOD SECURITY IN KAZAKHSTAN: THEORY, METHODOLOGY AND PRACTICE
}

\author{
* A. Dzhumabayeva ${ }^{1}$, D. Babash ${ }^{2}$, A. Kendzhasarova ${ }^{3}$, R.Arzikulova $^{4}$ \\ ${ }^{1}$ "Kazakh National Agrarian Research University» NP JSC. \\ 2,3 «ZHETYSU UNIVERSITY N.A. I. ZHANSUGUROV» NP JSC, Taldykorgan, Kazakhstan \\ ${ }^{4}$ Kazakh National Pedagogical University named after Abai, \\ Almaty, Kazakhstan \\ *e-mail: givi.gaza@mail.ru
}

Annotation. In the modern world, the logic of states' actions is subordinated to the idea of finding advantageous positioning in the new post-industrial information world, where the interests of states collide in the struggle for political influence, finance, and human capital. Economic leaders seeking to maintain their global dominance are increasingly violating the rules that they themselves once proclaimed. They are being overtaken and overtaken by new economies, which is why competition is becoming more and more deformed from the point of view of law and rules. Kazakhstan, as a country regaining its rightful place in the world, is experiencing exorbitant political and economic pressure from countries that consider themselves pillars of the current world order. However, throughout its history, the Republic of Kazakhstan has faced attempts to impose someone's political will and values on it. Contrary to this, our country acts on the world stage based on the understanding that the world system should be based on the principles of fair competition, respect for the culture and traditions of other countries, mutual assistance and cooperation.

Keywords: economy, development, agro-industrial complex, food security, product quality, competitiveness, agriculture.

The Eurasian Economic Union (EAEU) is an example of a new approach to the formation of an effective economic order, when countries on a voluntary, mutually respectful and equal basis build a unified system for managing integration processes. It is once again important for our country to make an economic breakthrough in a very short historical period, as it has been more than once, in order to consolidate not only its own position in the global economic space, but also the positions of its numerous allies. Without effective management, it is impossible to create an economic foundation for a new innovative economy. And without an efficient economy, a productive foreign policy loses one of the most important pillars [1]. Today, the EAEU has become an important springboard for developing new tools and approaches to managing economic alliances that can attract new allies and partners. However, this is not a spontaneous process, and therefore it needs fundamental and theoretical elaboration at each of the levels and directions of cooperation. Any crisis, as a rule, is a harbinger of economic growth, but only when exposing social and economic contradictions, it is used by state institutions as a driver and navigator, forming a fundamentally new economic policy and management mechanisms. It is worth noting that here we are talking not so much about un- 


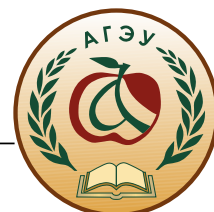

derstanding the causes of the crisis, as about building a fundamentally new toolkit for the progressive socio-economic development of the country. Slogans and actions should coincide, generating pragmatic managerial steps aimed at the final result. The aggravation of the political situation in the world has demonstrated the realities of the global conjuncture for Kazakhstan, sharply exposing the problem of national security, which is based on the economic strength of the country. Unification processes in the world are increasing and the development of the EAEU is becoming an important factor of stability for the Republic of Kazakhstan[2].

\section{Main provisions of the article.}

Currently, our defeats on the economic front are largely due to the disorientation of public administration, the withdrawal of the state from active and effective partnership with business.

The managerial style of public administration, as a rule, has a traditional character, alienated from the result, expressed in the role of the state as a kind of observer, macroregulator and "assistant" of business.

Globalization dictates new rules of the game in the international arena, when crosscountry competition gets a new round of its development.

Introduction. The expansion of transnational corporations and the ability of the country to oppose it with the market power of the economy predetermine the outcome of this struggle. The support of business and the incubation of its competitive advantages in the conditions of the global world order are becoming not just a new policy of the state, but a struggle for its survival. That is why, in our opinion, in Kazakhstan, the problem of effective public administration comes to the fore in overcoming the crisis [3]. Competition from the commodity segment has moved into the competition of management systems, both from business structures and states. Becoming a state leader and a locomotive of innovative economic development is not a political slogan, but a necessity. The alliance of the state and business in the innovation sphere in the modern world is significantly effective when the state undertakes the construction of infrastructure elements of the economic and risk management system. Business in the innovation sector always plays the "second number" after the state, picking up the most developed and effective developments for their further financing and adaptation in the market space. Only the creation of an effective set of state regulation tools can change the role of the state in the economic development of the country. An example of effective economic management is the Foundation "To the People of Kazakhstan", which attracted the interest of many companies in innovative cooperation with the state. With large-scale financing of this Fund, it can become a real global player in the market[4].

Methodology. Research methods include methods of economic, theoretical, logical and comparative analysis, synthesis and graphical method. The theoretical and methodological basis of the research was the development of leading foreign and domestic scientists in the field of management, agriculture. The regulatory framework consists of laws of Kazakhstan, decrees of the President of the Republic of Kazakhstan, resolutions of the Government of the Republic of Kazakhstan, international standards. Annual and financial reports at the country and regional level served as the informational and empirical basis of the study, ensuring the representativeness of the initial data, reliability, reliability and accuracy of conclusions, recommendations and proposals.

Results. In the context of globalization, the economic nature of the state is changing from a regulator to a navigator, a leader, a senior business partner directly interested in the development of high-margin export-oriented sectors of the national economy [5]. In fact, this is a managerial response of the state to the challenges of globalization and the intensification 


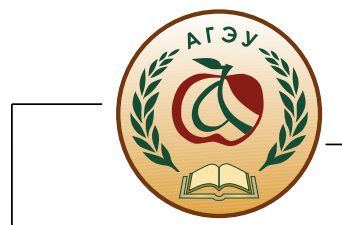

of cross-country competition. A special place in this competition belongs to the agricultural market, as a catalyst for the level of independence of the state in terms of its food security. Food security is an economic category officially accepted in international practice, which is used to characterize the state of the food market of a country or group of countries, as well as the world market, which ensures guaranteed access of all social groups of the population to vital food at any time and in volumes sufficient to achieve medical consumption standards. Almost a billion inhabitants of the planet receive an amount of food that is not sufficient to ensure a healthy lifestyle. First of all, 10 are residents of the countries of South and Southeast Asia and tropical Africa. The problem of food shortage in the post-war years has undergone significant changes in the direction of increased consumption and localization of poverty, but, nevertheless, demonstrates significant asymmetry across regions and states of the world. So, according to this factor, four groups of countries can be distinguished in the modern world:

- Firstly, these are the leaders of food security - Japan, Australia, North America, Western and Northern Europe, which demonstrate overproduction of food and are export donors of the world, supporting the world food balance. For some food items, including grain and sunflower oil, the Republic of Kazakhstan has joined this elite club in recent years;

- secondly, the UN WHO considers most countries in the regions of Latin America, Central Asia, southern Europe, ASEAN close to the norm of food consumption;

- thirdly, the who, the UN defines as "acceptable" level variations in the criteria of food security of the countries of the former Soviet Union, Eastern European countries, Indonesia, India and Egypt.

- fourth, it was a large group of developing countries, which form a significant part of the population of the planet and experiencing the full brunt of the struggle for physical survival;

- fifth, economic success is based on the quality of human capital, which forms a new management paradigm based on communication and continuous educational process. It is innovative management that is able to synthesize effective management decisions that act ahead of the curve.

With the development of globalization, not only multinational companies, but also all, without exception, states and interstate associations are moving to the concept of "risk management", when the factors of globalization do not make it possible to sustainably manage internal socio-economic systems [6].

These risks are based on:

- the absence of borders that ensure the containment of the movement of financial, information, human and other resources;

- uncompromising intercivilizational struggle of standards and lifestyle, as well as worldviews;

- an attempt to monopolize the regulation of international relations and the ideology of human development on the basis of the formed supranational public institutions of governance;

- unification of models of state structure and their forcible installation in the regions of the world without taking into account their historical, ethnic and national characteristics;

- deformation of the process of socialization of the individual from traditional methods of family upbringing and public education to information and communication technologies of a single global virtual space. 


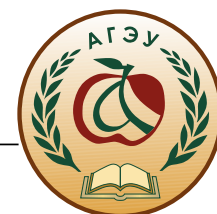

All these trends in the development of mankind are becoming a challenge for each state individually and require the search for solutions that ensure the stability of the social system.

The goal of the food policy is to ensure the accelerated development of all spheres of the agro-industrial complex, increase its innovative component, competitiveness, which will eventually become the basis of collective security, increase the standard of living and incomes of the population in each region of Kazakhstan [7]. The realization of the formulated goal dictates the need to solve the following tasks:

1. Implementation of a balanced economic policy using modern mechanisms and tools adequate to the global world order to manage the processes of integration and the formation of a single economic landscape.

2. Development and implementation of programs in the field of agriculture aimed at increasing the profitability of production, including through the innovative component, taking into account the specifics of the national interests of the EAC member states.

3. Formation of effective logistics for the free movement of goods and services, as well as labor and capital, while ensuring economic security.

4. Ensuring effective promotion of export-oriented agricultural products on world markets through the production of innovative products and the synergy of the EAEU.

5. Ensuring a competitive environment and effective forms of support for the agroindustrial complex for activities for accelerated development in the agricultural sector of various forms of ownership.

6. Implementation of comprehensive measures for the formation and maintenance of food security.

7. Development of a unified effective foreign economic policy of the Republic of Kazakhstan in the field of agriculture, ensuring priority development on the basis of mutually beneficial relations with partner states and international organizations, including the WTO.

8. Development of integration in the field of agricultural science, including breeding and seed production, plant protection, breeding, veterinary medicine, increasing soil fertility, improving land reclamation, introduction of progressive innovative technologies, including in the market of production of environmentally friendly food products and in other areas.

9. Coordination of work on training and retraining of personnel in managerial and agricultural specialties based on the latest achievements of scientific and technological progress in the agricultural sector.

10. Formation and ensuring the effective operation of a unified information system of the agricultural market, ensuring transparency of market processes throughout Kazakhstan and improving the business climate for all economic entities.

11. Coordination of investment policy aimed at sustainable development of exportoriented priority sectors of the single agricultural market.

12. Support for the development of cooperation between business structures - participants of the EAEU agro-industrial complex market, ensuring the efficiency of agribusiness and its competitiveness in the world market.

13. Development of industry models of interaction of business structures using the potential of interstate industry unions in the field of agriculture.

The most important criteria for the effectiveness of the implemented agro-industrial policy are increasing the competitiveness and export orientation of agricultural production, reducing costs, increasing incomes, profitability of agribusiness, as well as the development 


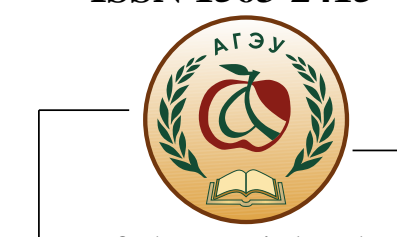

of the social sphere in rural areas, improving working conditions, which ultimately directly affects the localization of poverty among the rural population.

A separate block characterizing the effectiveness of agricultural policy is the growth of commodity exchange in the single agricultural market of the EAEU, an increase in the share in the production of environmentally friendly products and ensuring collective food security. A special place in the activities of the EAEU is given to the agrarian market and collective food security as the basis of the national security of the participating states.

Already at present, grain, sunflower oil, sugar, potatoes fully meet the consumption standards of the population and have a growing export potential.

On the contrary, dependence on imports for meat and milk remains, although the dynamics of meat production shows constant growth and by 2025 Kazakhstan will reach the level of self-sufficiency for this group of goods.

Kazakhstan occupies a prominent place in the regional agricultural market of the EAEU, but the level of food security of the Union countries lags far behind the developed countries of the world (Table 1).

Table 1. - Rating of the countries of the Eurasian Economic Union on the food security index in 2021.

\begin{tabular}{|c|c|c|}
\hline Rating & Country & Index value \\
\hline 43 & Russia & 63.8 \\
\hline 44 & Belarus & 63.5 \\
\hline 56 & Kazakhstan & 56.8 \\
\hline
\end{tabular}

Note: compiled by the authors.

During the functioning of any international economic organization, objective problems arise related to their management. Only through the efforts of national economies can we achieve a positive result and reach the leading positions in the world rankings.

Conclusions. Currently, there is a discussion about replacing the concept of "food security" with the concept of "food well-being". The difference lies in their optimistic and pessimistic approaches to providing food to the population. If "food security" is based on a system of threats to state security and represents a framework of protective state measures, then the concept of "food well-being" is based on a positive scenario of the development of the political situation around Kazakhstan. If food security is ensuring the minimum needs of the population or a policy of survival in an aggressive environment, then "food well-being" implies improving the well-being of people, improving the comfort of their residence on the territory of the Republic, reliability and stability of food supply, availability to consumers anywhere in the country of the usual food at an affordable price from the point of view of the consumer himself. It seems to us that the substitution of two concepts is illegal, since the Republic of Kazakhstan and its allies will have to be in an aggressive environment for a long time until a balanced polarization of the whole world takes place. In this regard, food security is a minimum program for Kazakhstan and its allies, and the Food Welfare Program can be part of a comprehensive social program for the development of human capital in the Republic of Kazakhstan and the EAEU countries, since by its nature it sets the task of providing competitive comfort for the population. 


\section{List of references:}

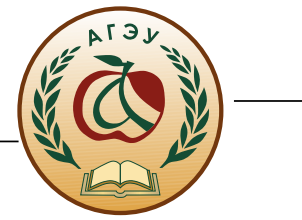

1. Агропромышленная политика Евразийского экономического союза.[ Electronic resource]. Access mode: URL: http://www.eurasiancommission.org/ru/Documents/APKrus_n.pdf (Accessed: September 11, 2021).

2. Всемирная продовольственная программа ООН. [Electronic resource]. URL: https://ru.wfp.org// (Accessed: October 19, 2021).

3. Доклад ОOH [Electronic resource]. URL: http://www.interfax.ru/world/459701 (Accessed: October 23, 2021).

4. Совершенствование межрегионального обмена в системе территориальноотраслевого разделения труда в агропромышленном производстве Евразийского экономического союза / Алтухов А.И., Силаева Л.П., Солошенко В.М., Солошенко Р.В., Трубилин А.И., Винничек Л.Б., Семенова Е.И., Кульчикова Ж.Т., Михайлушкин П.В., Яшина М.Л., Моисеев А.В., Измайлова С.А., Петрова И.Ф., Полутина Т.Н., Пятинский А.С., Солнцева О.В., Семенов В.А., Алексеев С.А., Дидык А.С., Захарова А.П. and oth.Moscow-Kostanay, 2017. - 296 p.

5. Добросоцкий В.И., Мастушкин М.Ю. Продовольственная политика и устойчивое развитие: проблемы соответствия и реализации // Дискурс, политика, управление: материалы IX Конвента РАМИ. - Moscow, 2016. Р. 312-317.

6. Ушачев И.Г. (2013). Продовольственная безопасность в рамках глобального партнерства. М. Издательство ИП Насирддинова В.В. 330 р. Р. 40-65, 65-80, 99-108, 147-172.

7. Кайгородцев А.А. (2006). Экономическая и продовольственная безопасность Казахстана. Вопросы теории, методологии, практики. Ust-Kamenogorsk: МедиаАльянс. - 384 p.

\section{List of references (транслитерация):}

1. Agropromyshlennaya politika Evrazijskogo ekonomicheskogo soyuza.[ Electronic resource]. Access mode: URL: http://www.eurasiancommission.org/ru/Documents/APKrus_n.pdf (Accessed: September 11, 2021).

2. Vsemirnaya prodovol'stvennaya programma OON. [Electronic resource]. URL: https://ru.wfp.org// (Accessed: October 19, 2021).

3. Doklad OON [Electronic resource]. URL: http://www.interfax.ru/world/459701 (Accessed: October 23, 2021).

4. Sovershenstvovanie mezhregional'nogo obmena v sisteme territorial'no-otraslevogo razdeleniya truda v agropromyshlennom proizvodstve Evrazijskogo ekonomicheskogo soyuza / Altuhov A.I., Silaeva L.P., Soloshenko V.M., Soloshenko R.V., Trubilin A.I., Vinnichek L.B., Semenova E.I., Kul'chikova ZH.T., Mihajlushkin P.V., YAshina M.L., Moiseev A.V., Izmajlova S.A., Petrova I.F., Polutina T.N., Pyatinskij A.S., Solnceva O.V., Semenov V.A., Alekseev S.A., Didyk A.S., Zaharova A.P. and oth..- Moscow-Kostanay, 2017. - 296 p.

5. Dobrosockij V.I., Mastushkin M.YU. Prodovol'stvennaya politika i ustojchivoe razvitie: problemy sootvetstviya i realizacii // Diskurs, politika, upravlenie: materialy IX Konventa RAMI. - Moscow, 2016. P. 312-317.

6. Ushachev I.G. (2013). Prodovol'stvennaya bezopasnost' v ramkah global'nogo partnerstva. M. Izdatel'stvo IP Nasirddinova V.V. 330 p. P. 40-65, 65-80, 99-108, 147-172.

7. Kajgorodcev A.A. (2006). Ekonomicheskaya i prodovol'stvennaya bezopasnost' Kazahstana. Voprosy teorii, metodologii, praktiki. Ust-Kamenogorsk: Media-Al'yans. 384 p. 


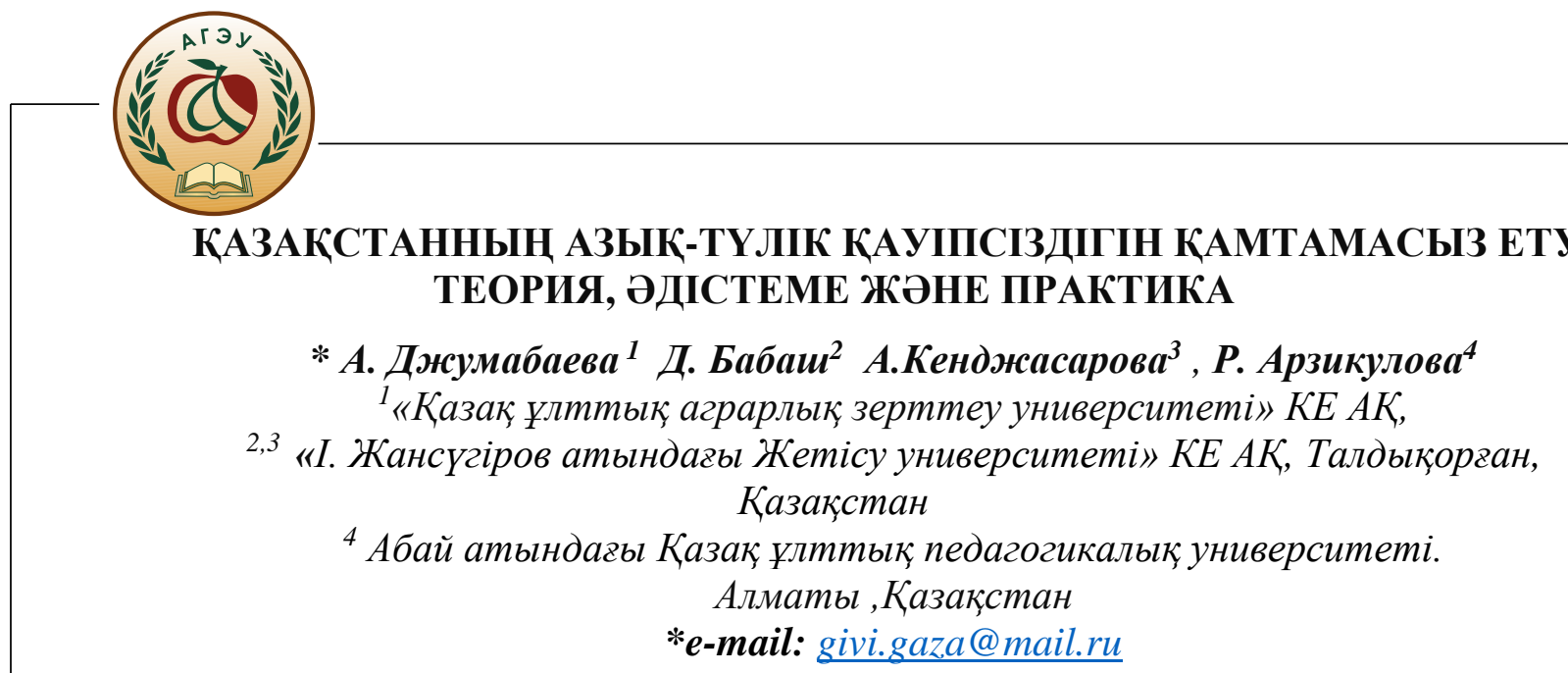

Түйін. Мақ̆алада интегращияльқ прочестерге қ̧атысу призмасы арқыльы Қазақсстан Республикасының азық-түлік құауіпсіздігін қ̧амтамасыз етудін негізгі теориялық және әдіснамалық негіздері құарастырылады. Елімізде азық-түлік қ̧ауіпсіздігін қзамтамасыз етудің негізгі міндеттері айқындалды. Жұмыста әлемдік рейтингті ескере отырыл, Қазақсстанның ЕАЭО қ̧атысушы елдерінің азық-түлік қ̧ауіпсіздігін құамтамасыз ету рейтингіндегі ұстанымы сипатталган. Ел халқын азық-түлікпен аграрлық қ̧амтамасыз ету жүйесін жетілдірудің негізгі базыттары ұсынылды. Мақ̆алада өнімнің сапасын арттыру және азық-түлік қ̧ауіпсіздігін тиімді ққамтамасыз ету жолдары көрсетілген.

Түйін сөздер: экономика, даму, агроөнеркәсіптік кешен, азық-түлік қ̧ауіпсіздігі, өнім сапасы, бәсекеге құабілеттілік, ауыл шаруашыльвы.

\title{
ОБЕСПЕЧЕНИЕ ПРОДОВОЛЬСТВЕННОЙ БЕЗОПАСНОСТИ КАЗАХ- СТАНА: ТЕОРИЯ, МЕТОДОЛОГИЯ И ПРАКТИКА
}

\author{
* А. Джумабаева ${ }^{1}$, Д. Бабаш ${ }^{2}$, А.Кенджасарова ${ }^{3}$, Р. Арзикулова ${ }^{4}$ \\ ${ }^{1}$ НАО «Казахский национальный аграрный исследовательский университет», \\ ${ }^{2,3}$ НАО «Жетьсуский университет им. И. Жансугурова», \\ Талдыкорган, Казахстан \\ ${ }^{4}$ Казахский наџиональный педагогический университет им. Абая, \\ Алматы, Казахстан \\ *e-mail: givi.gaza@mail.ru
}

Резюме. В статье рассматриваются основные теоретико-методологические основы обеспечения продовольственной безопасности Республики Казахстан через призму участия в интеграционных прочессах. Определены основные задачи обеспечения продовольственной безопасности в стране. В работе охарактеризована позиция Казахстана в рейтинге обеспечения продовольственной безопасности стран участнии ЕАЭС с учетом мирового рейтинга. Предложены основные направления совершенствования системы аграрного обеспечения продовольствием населения страны. В статье указаны пути повышения качества продукции и эффективного обеспечения продовольственной безопасности.

Ключевые слова: экономика, развитие, агропромышленный комплекс, продовольственная безопасность, качество продукиии, конкурентоспособность, сельское хозяйство. 
ISSN 1563-2415

Джумабаева Айгуль Муратовна

Старший преподаватель кафедры «Менеджмент и организащия агробизнеса» имени Х.Д. Чурина, магистр наук, НАО «Казахский национальный аграрный исследовательский университет».

Бабаш Диас Бекмукамбетуль

Преподаватель-лектор ОП государственное и местное управление, менеджмент,

Магистр финансов, НАО «Жетысуский университет им. И. Жансугурова».

\section{Кенджасарова Айгерим Муратовна}

Преподаватель-ассистент ОП государственное и местное управление, менеджмент,

Магистр наук, НАО «Жетьсуский университет им. И. Жансугурова».

Арзикулова Рахат Калмахамбетовна

Стариий преподаватель кафедры «Экономические специальности»,

Кандидат экономических наук, Казахский нацииональный педагогический университет им.Абая.

\section{Дюжумабаева Айгуль Муратовна}

Х. Д. Чурин атындавы «Менеджмент және агробизнесті ұйымдастыру» кафедрасының ава оқыьтуш, вылымм магистрі, «Қазақ ұлттық аграрлық зерттеу университеті» КЕ АҚ.

\section{Бабаш Диас Бекмұқамбетұль}

Мемлекеттік және жергілікті басқ̧ару, менеджмент білім беру бавдарламаларының оқытушылекторы, қ̧аржы магистрі, «I. Жансүгіров атындавы Жетісу университеті» КЕАК.

\section{Кенджасарова Айгерим Муратовна}

Мемлекеттік және жергілікті басқ̧ару, менеджмент білім беру бавдарламаларының оқыытушыассистент, гылым магистрі, «I. Жансүгіров атындагы Жетісу университеті» КЕАҚ.

\section{Арзикулова Рахат Калмахамбетовна}

«Экономикалық мамандықттар» кафедрасының ава оқұытушы, Экономика вылымыныңң кандидаты, Абай атындавы Қазақұ ұлттық педагогикалық университеті.

\section{Dzhumabayeva Aigul Muratovna}

Senior Lecturer of the Department «Management and Organization of Agribusiness» named after H.D. Churin, master of science, "Kazakh National Agrarian Research University» NP JSC.

\section{Babash Dias Bekmukambetuly}

Teacher-lecturer of educational programs state and local government, management,

Master of finance, "Zhetysu University n.a. I. Zhansugurov» NP JSC.

Kendzhasarova Aigerim Muratovna

Teacher-assistant of educational programs state and local administration, management,

Master of science, "Zhetysu University n.a. I. Zhansugurov» NP JSC.

\section{Arzikulova Rakhat}

Senior Lecturer of the Department of Economic Specialties. Candidate of economic of sciences, Kazakh National Pedagogical University named after Abai 


\section{ПРАВИЛА ДЛЯ АВТОРОВ ЖУРНАЛА}

(с учетом изменений в Требованиях к научным изданиям для включения их в Перечень изданий, рекомендуемых для публикации результатов научной деятельности-Приказ Министра образования и науки Республики Казахстан от 30 апреля 2020 года № 170)

Журнал «Статистика, учет и аудит» (в дальнейшем - Журнал) публикует оригинальные работы ученых и специалистов научно-исследовательских организаций, высших учебных заведений, организаций и административных структур Казахстана, а также иностранных авторов. В журнале публикуются оригинальные статьи по научным направлениям статистики, учета и аудита, микро и макроэкономические вопросы международной и отечественной экономики, финансов, информатики и педагогики. Также публикуются рецензии, хроники научной жизни и др. материалы, имеющие отношение к деятельности Учредителя журнала.

Обязательными условиями для публикации являются:

1.Соответствие публикуемых научных статей (в том числе обзоров) заявленной цели и тематическому направлению журнала. Научная статья - изложение собственных выводов и промежуточных или окончательных результатов научного исследования, экспериментальной или аналитической деятельности, содержащее авторские разработки, выводы, рекомендаций ранее не опубликованные и обладающие новизной; или посвященное рассмотрению ранее опубликованных научных статей, связанных общей темой (систематический обзор).

2.Структура научной статьи включает название, аннотацию, ключевые слова, основные положения, введение, материаль и методы, результаты, обсуждение, заключение, информацию о финансировании (при наличии), список литературы. В каждой оригинальной статье (за исключением социально-гуманитарного направления) обеспечивается воспроизводимость результатов исследования, описывается методология исследования с указанием происхождения оборудования и материалов, методов статистической обработки данных и других способов обеспечения воспроизводимости. Содержание других типов публикаций не превышает 10\% (десять) от общего количества статей в номере. При этом автор или коллектив авторов вносят значительный вклад в концепцию, научный дизайн, исполнение или интерпретацию заявленного научного исследования и создание научной статьи. Наличие библиографической информации - заголовка статьи, аннотации, ключевых слов, информации об авторах на английском языке обязательно.

2.1 В аннотации (аңдатпа, abstract) публикуемой статьи на языке статьи излагаются суть и использованные методы исследования, суммируются наиболее важные результаты и их значимость. Объем аннотации составляет не более 300 слов (минимальный объем-100 слов). 


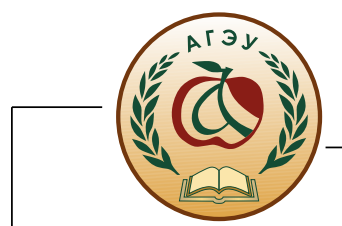

2.2 Резюме (түйін, summary) на двух не на языке статьи (казахском, русском и английском) языках. Например, резюме и summary- это не переводы аңдатпа, а краткое изложение о статье на русском и английском языках (если статья написана на казахском) и рекомендуется их приводить после списка литературы.

2.3 Ключевые слова (түйінді сөздер, key words) предназначены для поиска текста статьи и определения ее предметной области. Например, они приводятся после аннотации (если статья написана на русском) и двух резюме (түйін, summary). Ключевые слова должны обеспечить наиболее полное раскрытие содержания статьи.

2.4 Информация об авторах - имена (Фамилия И.О. авторов), аффилиации (полное название учреждения, которое представляет автор (авторы), название страны, и адреса всех авторов публикаций, в том числе с указанием основного автора-выделить звездочкой (*), е-таil (основного автора).

3. Список литературы. Ссылки на источники в тексте статьи даются только в квадратных скобках (без цитирования [12], при цитировании или пересказе авторского текста [12, с. 29]). Используемая литература, указываемая в ссылках, дается в конце статьи пронумерованной и в порядке упоминания по авторам. Архивные материалы в список не включаются, ссылки на них помещаются в тексте в круглых скобках. При использовании в статье: источников законодательных, нормативно-правовых актовссылки на них делать в тексте сразу же после них, а источников из электронных ресурсов или удаленного доступа (Интернета) в списке литературы приводится библиографическая запись источника и ссылка на сетевой ресурс с полным сетевым адресом в Интернете. Желательно указывать дату обращения к ресурсу. Список литературы предоставляется на языке оригинала и должен состоять не более чем из 20 наименований.

3.1 Наличие транслитерированных списков литературы (используемых источников) к каждой статье. Существуют различные системы транслитераций. Предложение редакции по транслитерации (вы имеете право найти другой способ):

3.1. На данной странице Вы можете выполнить транслит - онлайн русских букв латиницей:

Транслитерация с русского на английский онлайн

https://lim-english.com/posts/transliteratsiya-s-russkogo-na-angliiskij/

4. Ответственность за содержание статей несут авторы.

5. Этические принципы, которыми должен руководствоваться автор научной публикации. Представление статьи на рассмотрение в редакцию подразумевает, что она содержит полученные автором (коллективом авторов) новые научные результаты, которые ранее нигде не публиковались. Автор должен осознавать, что несет персональную ответственность за представляемый текст рукописи. Это предполагает соблюдение следующих принципов:

5.1. Автор статьи гарантирует, что предоставляет редакции журнала достоверные результаты выполненной научной работы или исследования. Заведомо ложные или 
сфальсифицированные утверждения приравниваются к неэтичному поведению и являются неприемлемыми.

5.2. В случае, если главный редактор журнала запрашивает у автора научной статьи ее исходные данные для рецензирования, автор, если это возможно, должен быть готов предоставить открытый доступ к таким данным; автор также берет на себя обязательство сохранять исходные материалы статьи в течение разумного периода, прошедшего после ее публикации.

5.3. Автор гарантирует, что результаты исследования, изложенные в рукописи, представляют собой самостоятельную и оригинальную работу. В случае использования фрагментов чужих работ или заимствования утверждений других авторов, в статье должны быть оформлены соответствующие библиографические ссылки с обязательным указанием автора и первоисточника. Все статьи проходят обязательную проверку через систему «Антиплагиат». Все статьи проверяются на предмет обнаружения плагиата (оригинальность должна быть не менее 70\%). Применяется лицензионная программа АНТИПЛАГИАТ.ВУЗ Договор № 1065 от 29 декабря 2020 г.) Чрезмерные заимствования, а также плагиат в любых формах, включая неоформленные цитаты, перефразирование или присвоение прав на результаты чужих исследований, являются неэтичными и неприемлемыми действиями. Статьи, представляющие собой компиляции из материалов, ранее опубликованных другими авторами, без их творческой переработки и собственного авторского осмысления, редакцией журнала к публикации не принимаются.

5.4. Автор безусловно признает вклад всех лиц, так или иначе повлиявших на ход исследования или определивших характер представленной научной работы. В частности, в статье должны быть сделаны библиографические ссылки на отечественные и зарубежные публикации, которые имели значение при проведении исследования. Информация, полученная в частном порядке путем разговора, переписки или обсуждения с третьими лицами, не должна использоваться без получения открытого письменного разрешения от ее источника. Все источники должны быть раскрыты. Даже в том случае, если используемые в статье письменные или иллюстративные материалы получены от большого числа людей, автору статьи необходимо представить в редакцию все соответствующие разрешения на использование этих материалов.

5.5. Автор гарантирует, что представленная в журнал рукопись статьи не находится на рассмотрении редакции другого научного журнала и не была ранее опубликована в другом журнале. Несоблюдение этого принципа расценивается как грубое нарушение этики публикаций и дает основание для снятия статьи с рецензирования. Текст статьи должен быть оригинальным, то есть публиковаться в представленном виде в периодическом печатном издании впервые. Если элементы рукописи ранее были опубликованы в другой статье, автор обязан сослаться на более раннюю работу и указать, в чем состоит существенное отличие новой работы от предыдущей. Дословное копирование собственных работ и их перефразирование неприемлемы, они могут быть использованы только как основа для новых выводов. 


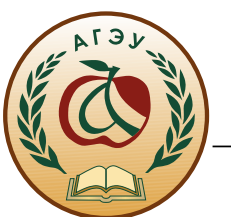

5.6. Автор статьи гарантирует правильность списка соавторов. В числе соавторов должны быть указаны все лица, внесшие существенный интеллектуальный вклад в концепцию, структуру, а также в проведение или интерпретацию результатов представленной работы. Другим лицам, чье участие в представленной в журнал работе ограничилось некоторыми ее аспектами, должна быть выражена благодарность. Автор статьи должен также гарантировать, что все соавторы ознакомлены с окончательным вариантом статьи, одобрили его и согласны с ее представлением к публикации. Все указанные в статье соавторы несут совокупную ответственность за ее содержание. Если статья является мультидисциплинарной работой, соавторы могут также принимать на себя ответственность за свой личный вклад в работу, продолжая при этом нести коллективную ответственность за результат исследования в целом. Недопустимо указание в качестве соавторов статьи лиц, не принимавших участия в исследовании.

5.7. В случае обнаружения существенных ошибок или неточностей в статье на этапе ее рассмотрения или после ее опубликования автор обязан незамедлительно уведомить об этом редакцию журнала и принять совместное решение о признании ошибки и/или ее исправлении в максимально короткие сроки. Если редакция узнает от третьего лица, что опубликованная работа содержит существенные ошибки, автор обязан незамедлительно исправить их либо предоставить редакции доказательства правильности ранее предоставленной им информации.

5.8. Автор обязуется указывать в своих рукописях все источники финансирования работы, заявлять о возможных конфликтах интересов, которые могут повлиять на результаты исследования, их интерпретацию, а также на суждения рецензентов. Потенциальные конфликты интересов должны быть раскрыты как можно раньше.

6. Поступившие от авторов научные статьи проходят первичный контроль на комплектность и правильность оформления. Далее статья направляется на предмет обнаружения плагиата (оригинальность должна быть не менее 70\%). Применяется лицензионная программа АНТИПЛАГИАТ.ВУЗ Договор № 1065 от 29 декабря 2020 г.), после чего, научные статьи, поступившие в редакцию, проходят обязательное слепое рецензирование порядок прохождения, которых описан в разделе Рецензирование.

При отрицательном отзыве рецензентов редакция Журнала обязуется сообщать авторам все комментарии об их работе, сделанные рецензентами, если только они не содержат обидные или клеветнические замечания.

7. В конце статьи предоставляются заполненные формы для размещения сборника статей в Научной электронной библиотеке (eLibrary.ru) и включения сборника статей в Российский индекс научного цитирования (РИНЦ):

\section{ФОРМА}

для размещения сборника статей в Научной электронной библиотеке (eLibrary.ru) и включения сборника статей в Российский индекс научного цитирования (РИНЦ)

1. Название статьи: на казахском, русском и английском языках 
2. Сведения об авторе (авторах):

- фамилия, имя, отчество (полностью) автора (авторов) с указанием ученой степени и ученого звания (при наличии) на трех языках:

- место работы автора (авторов) (должность и организация) на трех языках:

- контактная информация:

e-mail автора (авторов) - тел.номер автора (авторов) -

8. Редакция оставляет за собой право редакторской правки.

Технические требования

1. Общий объем статьи, включая аннотацию, ключевые слова, литературу, таблицы и рисунки не должен превышать 6-8 страниц. Исключение составляют заказные и обзорные статьи.

2. Статьи должны быть оформлены в строгом соответствии шрифтом гарнитуры Times New Roman.

МРНТИ

\section{Схематический пример оформления статьи}

УДК 339.74

DOI (Digital Object Identifier) xxxxxxxxxx

По центру приводятся: Название статьи

(Поля: сверху - 2 см., слева-3 см., справа -1,5 см. Шрифт полужирный. Кегль-14 пт, межстрочный интервал - одинарный.)

Фамилии и инициалы авторов (напр.И.В.Иванов, Ю.П.Крылов)

Полное название учреждения, которое представляе(ю)т автор(ы) с указанием города и страны, электронного адреса основного автора выделением надстрочной звездочкой. Если авторы из разных учреждений, то соответствие между автором и учреждением устанавливается надстрочными индексами, например:

\section{${ }^{*}$ И.В. Иванов ${ }^{1}$, Ю.П. Крылов ${ }^{2}$}

${ }^{1}$ Алматинский гуманитарно-экономический университет, Алматы, Казахстан 2 Международная академия бизнеса, Алматы, Казахстан e-mail: ivanov@mail.ru

- Аннотация.

- Ключевые слова.

- Текст статьи: Поля: сверху, снизу - 2 см., слева - 3 см., справа -1,5 см. Шрифт Times New Roman. Кегль-14 пт. Абзацный отступ-1,25 см., межстрочный интервал одинарный).

- Список литературы. Транслитерированный список литературы (References)

- После списка литературы приводятся:

Название статьи перед каждым резюме на двух не на языке статьи (казахском, русском и английском) языках. 
ISSN 1563-2415

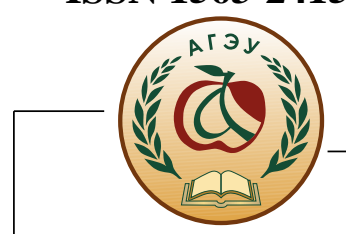

После каждого названия статьи приводятся см. выше (последовательно) пп. 2.4, 2.2, 2.3 Руководства для авторов

3. Таблицы и рисунки с названиями должны быть пронумерованы по порядку (если их несколько). Нумерация таблицы (Таблица 1.) должна быть расположена вверху слева выше названия таблицы через абзацный отступ.

4. Рисунки, фотографии, таблицы должны быть четкими и контрастнымив формате jpg, иметь разрешение не менее 300 dpi, подрисуночные надписи к ним должны быть расположены ниже рисунка по центру. Цветные рисунки, диаграммы не допускаются.

5. На рисунках должен быть минимум буквенных и цифровых обозначений, обязательно объясненных в статье или подрисуночных подписях.

6. Необъясненные сокращения слов, имен, названий, кроме общепринятых, не допускаются. Аббревиатуры расшифровываются после первого появления в тексте, например: Организация по экономическому сотрудничеству и развитию (ОЭСР).

7. Упомянутые в статьях единицы измерения должны соответствовать Международной системе единиц СИ.

8. Математические формулы должны быть набраны в Microsoft Education (каждая формула - один объект). Нумеровать следует лишь те формулы, на которые имеются ссылки.

9. Редакция не занимается литературной и стилистической обработкой статей. Материалы, статьи не возвращаются

10. Авторам для рассмотрения статьи необходимо представить рукопись на сайт www.sua.aesa.kz, и копию статьи со всеми сопроводительными документами согласно требованию направить на e-mail: zhurnal.aesa.99@ mail.ru :

10.1. Электронную версию статьи;

10.2.Наукометрическую базу данных для РИНЦ

10.3. Представить сканированную копию квитанцию об оплате за публикацию статьи и квитанцию об оплате за присвоение DOI (Digital Object Identifier) авторам, (только после подтверждения редакцией Журнала статьи к опубликованию).

ВНИМАНИЕ: DОI (Digital Object Identifier) присваивается регистрационным агентством International DOI Foundation (Интернэйщенел ДОИ Фаундэйщен). 